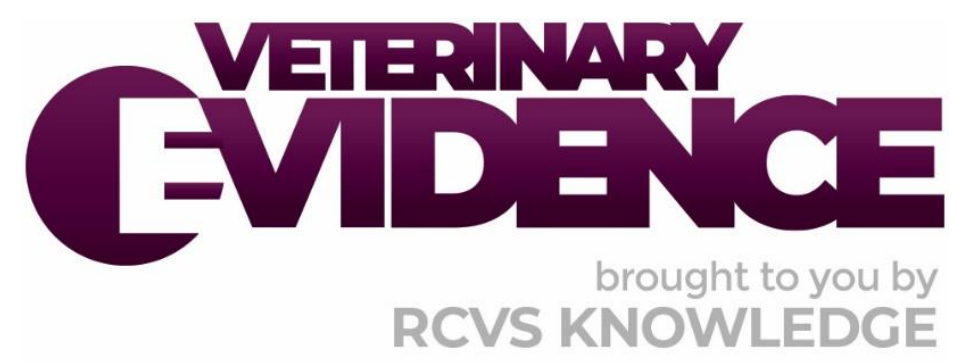

\title{
Does intra-articular injection of antimicrobials alongside corticosteroids or other medications reduce the risk of synovial sepsis?
}

\author{
A Knowledge Summary by
}

Helen Braid BSc (Hons) BVetMed CertAVP FHEA MRCVS ${ }^{1^{*}}$

\footnotetext{
${ }^{1}$ University of Liverpool, Institute of Veterinary Science, Liverpool, L69 3GH

* Corresponding Author (H.Braid@liverpool.ac.uk)
}

ISSN: 2396-9776

Published: 30 Oct 2019

in: Vol 4, Issue 4

DOI: 10.18849/VE.V4I4.194

Reviewed by: Ellen Singer (BA, DVM, DVSc) and Lynn Martin (DVM, MPH, DACVIM (LAIM))

Next Review Date: 26 Feb 2021 
KNOWLEDGE SUMMARY

\section{PICO question}

In horses, does treatment with intra-articular antimicrobials concurrently with intra-articular corticosteroids reduce the risk of iatrogenic synovial sepsis compared to intra-articular corticosteroids alone?

Clinical bottom line

From the current literature, there is no evidence showing that intra-articular injection of antibiotics in conjunction with corticosteroids reduces the risk of synovial sepsis. However, the intra-articular injection of polysulphated glycosaminoglycans (PSGAGs) in combination with corticosteroids was noted as a risk factor for developing iatrogenic synovial sepsis and therefore concurrent antibiotic injection when administering PSGAGs may be warranted. The reported frequency of infection following intra-articular injections was very low $(0.02-0.08 \%)$. An overall prevalence of iatrogenic synovial sepsis following all intra-articular injections based on data from all included studies was calculated as $0.02 \%$ ( $\mathrm{Cl} 0.02-0.03 \%)$. However, due to the paucity of literature on the topic, further studies are required in this field to determine more accurate clinical recommendations.

\section{Clinical Scenario}

Antimicrobials such as amikacin sulphate or gentamicin sulphate are often added to corticosteroid preparations when performing intra-articular injections in horses. This summary aims to determine whether the risk of iatrogenic synovial sepsis increases in the absence of these antimicrobials and to consider whether injecting them concurrently with intra-articular corticosteroids is necessary.

\section{The evidence}

Of the three studies examined, only two studies directly evaluated the prevalence of iatrogenic synovial sepsis following intra-articular injection. Two out of the three studies were retrospective analyses of medical records (Smith et al., 2018 and Steel et al., 2013) and one was a survey based study with retrospective analyses of medical records submitted by questionnaire respondents (Gillespie et al., 2016). The searches also revealed an abstract by Smith et al. (2013) which was later published as a full study (Smith et al., 2018) and for the purposes of avoiding data replication, only the full study has been included.

The scientific literature surrounding this topic was sparse and of inconsistent quality. There were no randomised controlled trials evaluating the risk of iatrogenic synovial sepsis following corticosteroid administration. Most studies comprised retrospective analyses of medical records, which are considered midlevel in the hierarchy of evidence-based medicine (Murad et al., 2016). The number of cases of iatrogenic synovial sepsis was very low in all included studies; therefore evaluating risk factors using multivariable models may have been biased by a low number of events per variable. All included studies were likely to have insufficient statistical power to identify a true difference in incidence between different treatments (Peduzzi et al., 1996). 


\section{Summary of the evidence}

Where prevalence and $95 \%$ confidence intervals $(\mathrm{Cl})$ were not provided in the publication, the author performed calculations where published data permitted using Epitools epidemiological calculators (Ausvet Pty Ltd., 2019). (Italics denote author calculations).

Steel, C.M., Pannirselvam, R.R., \& Anderson, G.A. (2013)

\begin{tabular}{|c|c|}
\hline Population: & $\begin{array}{l}\text { 16,624 intra-articular injections performed in } 1103 \text { Thoroughbred } \\
\text { racehorses. }\end{array}$ \\
\hline Sample size: & 16,624 injections in 1103 horses. \\
\hline Intervention details: & $\begin{array}{l}\text { - Cases included 16,624 joints injected in } 1103 \text { horses over a } 45 \\
\text { month period from } 31 \text { March } 2002 \text { to } 31 \text { December 2005. 15,934 } \\
\text { of these injections included corticosteroids. } \\
\text { - Control group included all horses given intra-articular medication } \\
\text { (IAM) on the same day, day before or the day after septic cases } \\
\text { (224 control horses with } 13 \text { infected joint cases - no specific data } \\
\text { was provided on injections for each case). } \\
\text { - Standardised aseptic preparation procedure was used. Hair was } \\
\text { not clipped and was scrubbed with } 4 \% \text { chlorhexidine for a } \\
\text { minimum of } 2 \text { minutes, then } 70 \% \text { alcohol wipes. } \\
\text { - Injections included corticosteroid (triamcinolone, } \\
\text { betamethasone, dexamethasone or methylprednisolone) with or } \\
\text { without amikacin sulphate, plus other unspecified medications. } \\
\text { Doses were not recorded. } \\
\text { Non-sterile dressing applied to all except stifle and shoulder } \\
\text { joints, where no dressing was applied. }\end{array}$ \\
\hline Study design: & $\begin{array}{l}\text { Retrospective and prospective descriptive study, with nested } \\
\text { matched case-control. }\end{array}$ \\
\hline Outcome studied: & $\begin{array}{l}\text { Diagnosis of septic arthritis within 1-19 days following intra-articular } \\
\text { injection and identification of any risk factors for this complication. } \\
\text { Septic arthritis was diagnosed if synovial fluid bacterial culture was } \\
\text { positive or if synovial fluid analysis revealed elevated total leucocyte } \\
\text { count }\left(>5.0 \times 10^{9} / \mathrm{L} \text { ) with a predominance of neutrophils }(>80 \%) \text { and }\right. \\
\text { increased total protein (>25 g/L). }\end{array}$ \\
\hline $\begin{array}{l}\text { Main findings: } \\
\text { (relevant to PICO question): }\end{array}$ & $\begin{array}{l}\text { - Of 16,624 joints injected in } 1103 \text { horses, septic arthritis occurred } \\
\text { in only } 13 \text { joints ( } 13 \text { horses). } \\
\text { - The risk of septic arthritis following intra-articular injection was } \\
\text { one case per } 1279 \text { injections or } 7.8 \text { per } 10,000 \text { joints (prevalence } \\
0.08 \% \text { [ } \mathrm{Cl} 0.05-0.13 \%] \text { ). } \\
\text { - Of the } 13 \text { septic cases, } 12 \text { horses were injected with a } \\
\text { corticosteroid plus or minus sodium hyaluronate (individual case } \\
\text { details unspecified) and one was injected with a homeopathic } \\
\text { anti-inflammatory product. } \\
\text { - Risk factors identified were veterinary surgeon and type of } \\
\text { corticosteroid. } \\
\text { Betamethasone had a lower risk of septic arthritis than } \\
\text { dexamethasone. }\end{array}$ \\
\hline
\end{tabular}




\begin{tabular}{|c|c|}
\hline & $\begin{array}{l}\text { When data for each joint location was compared there was no } \\
\text { significant difference in the number of cases. } \\
\text { None of the } 824 \text { joints injected with amikacin developed septic } \\
\text { arthritis. Of the } 15,800 \text { joints not injected with amikacin, } 13 \\
\text { developed iatrogenic synovial sepsis. There was no statistically } \\
\text { significant association between the absence of amikacin and } \\
\text { development of synovial sepsis (Fisher's exact test } P>0.99 \text { ). }\end{array}$ \\
\hline Limitations: & $\begin{array}{l}\text { - The effect of the individual performing skin preparation was not } \\
\text { studied because information was unavailable for seven of the } 13 \\
\text { septic cases and for } 50 \% \text { of the nonseptic cases. } \\
\text { - Study did not clarify whether veterinary surgeon or assistant } \\
\text { performed skin preparation. Due to certain veterinary surgeons } \\
\text { having an apparently higher rate of septic cases than others, this } \\
\text { would have been useful information in order to determine if } \\
\text { there were differences in aseptic technique despite a } \\
\text { standardised procedure being in place. } \\
\text { - Nonsterile dressing applied to all except stifle and shoulder } \\
\text { joints, where no dressing was applied. } \\
\text { - Medication doses were not recorded so association between } \\
\text { corticosteroid dose and septic cases could not be evaluated. } \\
\text { Statistical validity of results is limited by a large number of } \\
\text { injections with relatively low number of septic cases for } \\
\text { comparison (resulting in a low number of events per variable for } \\
\text { analysis of risk factors). }\end{array}$ \\
\hline
\end{tabular}

\begin{tabular}{|c|c|}
\hline \multicolumn{2}{|c|}{ Gillespie, C.C., Adams, S.B., \& Moore, G.E. (2016) } \\
\hline Population: & $\begin{array}{l}\text { Equine veterinarians who were members of the American } \\
\text { Association of Equine Practitioners (AAEP) in } 2014 .\end{array}$ \\
\hline Sample size: & $\begin{array}{l}241 \text { surveys were returned containing details of } 319,760 \text { intra- } \\
\text { articular injections. }\end{array}$ \\
\hline Intervention details: & $\begin{array}{l}\text { - A link to an online survey was distributed to all members of the } \\
\text { AAEP via email a total of three times between } 17 \text { March and } 9 \\
\text { May } 2014 . \\
\text { - The survey consisted primarily of multiple choice questions } \\
\text { about intra-articular injection site preparation methods, } \\
\text { injection methods, types of medication used and aftercare. } \\
\text { - Several open questions and written responses were also } \\
\text { included. } \\
\text { Guidelines were provided for determining joint sepsis. Medical } \\
\text { records for septic cases were requested and analysed. }\end{array}$ \\
\hline Study design: & Retrospective survey based cross-sectional study. \\
\hline Outcome studied: & $\begin{array}{l}\text { Reported rate of joint sepsis following intra-articular injection. } \\
\text { Guidelines for diagnosing sepsis included one or more of: increased } \\
\text { lameness score attributed to the injected joint, periarticular swelling, } \\
\text { joint effusion, cloudy or turbid synovial fluid, elevated total protein }\end{array}$ \\
\hline
\end{tabular}




\begin{tabular}{|c|c|}
\hline & $\begin{array}{l}\text { of the synovial fluid and elevated nucleated cell count of synovial } \\
\text { fluid. }\end{array}$ \\
\hline $\begin{array}{l}\text { Main findings: } \\
\text { (relevant to PICO question): }\end{array}$ & $\begin{array}{l}\text { Only } 26.6 \% \text { of respondents ( } 64 / 241 \text { surveys) provided data } \\
\text { regarding joint sepsis. } 67 / 319,760 \text { injected joints became septic } \\
\text { following injection; } 2.10 \text { septic joints per } 10,000 \text { intra-articular } \\
\text { injections (prevalence } 0.02 \% \text { [Cl } 0.02-0.03 \%] \text { ). } \\
\text { No significant reduction in joint sepsis was noted with the } \\
\text { concurrent intra-articular injection of antimicrobials. } \\
\text { Infection rates were significantly lower when: } \\
\text { - Veterinary surgeons prepared their own injection sites } \\
\text { - Veterinary surgeons had fewer than } 20 \text { years of practice } \\
\text { experience. } \\
\text { Infection rates were significantly higher when: } \\
\text { - Hair was removed at the injection site. } \\
\text { Some findings were significant on the univariable analysis but were } \\
\text { not retained in the final multivariable model. These included: } \\
\text { - Lower infection rates when the intra-articular injection site was } \\
\text { prepared for longer than } 7 \text { minutes } \\
\text { - Lower infection rates when surgeons wore sterile or non-sterile } \\
\text { gloves when performing the injection } \\
\text { Higher infection rates when veterinary surgeons used the same } \\
\text { needle to draw up medications and perform the injection. }\end{array}$ \\
\hline Limitations: & $\begin{array}{l}\text { - Horses with septic joints diagnosed by one veterinary surgeon } \\
\text { but injected by another (i.e. second opinions) were not included } \\
\text { in the study. This could have falsely lowered the apparent } \\
\text { infection rate, as approximately } 60 \% \text { of respondents reported } \\
\text { treating infections in horses that were injected by other } \\
\text { veterinary surgeons. } \\
\text { - Risk of misclassification bias - the method of diagnosing synovial } \\
\text { sepsis was recommended in the study, though the true method } \\
\text { of diagnosis may have varied between veterinary respondents. } \\
\text { - Study was questionnaire based and thus open to non-response, } \\
\text { response and recall bias. } \\
\text { Response rate was low with only } 241 \text { respondents, which } \\
\text { equates to a response rate of around } 2.5 \% \text { ( } 241 \text { responses from } \\
\text { around } 9600 \text { veterinarians receiving the survey), with only } 26.6 \% \\
\text { of respondents (64/241) providing data on joint infections. } \\
\text { Statistical validity of results is limited by a large number of } \\
\text { injections with relatively low number of septic cases for } \\
\text { comparison (resulting in a low number of events per variable for } \\
\text { analysis of risk factors). } \\
\text { Exact numbers of corticosteroid injections and how many of } \\
\text { these were septic were not provided, limiting the reliability of } \\
\text { interpretation of these results in direct relevance to the PICO } \\
\text { question. }\end{array}$ \\
\hline
\end{tabular}




\begin{tabular}{|c|c|}
\hline Population: & $\begin{array}{l}\text { Case records for every horse that received intra-synovial } \\
\text { medications performed by } 10 \text { ambulatory clinicians in one UK } \\
\text { equine hospital between } 1 \text { January } 2006 \text { and } 31 \text { December } 2011 \text {. }\end{array}$ \\
\hline Sample size: & 9456 intra-synovial injections in 1732 horses over 4331 sessions. \\
\hline Intervention details: & $\begin{array}{l}1732 \text { horses receiving therapeutic intra-synovial injections using } \\
\text { standardised aseptic technique. } \\
\text { - Records were cross-referenced against admissions of synovial } \\
\text { sepsis cases to the hospital and against cytology submissions. } \\
\text { Post-medication sepsis was considered if the horse developed } \\
\text { two or more of four signs of synovial sepsis within } 8 \text { weeks of } \\
\text { medication (listed below) and failed to respond to conservative } \\
\text { therapy. }\end{array}$ \\
\hline Study design: & Retrospective analysis of medical records. \\
\hline Outcome studied: & $\begin{array}{l}\text { Prevalence of iatrogenic synovial sepsis following intra-synovial } \\
\text { injections. } \\
\text { Synovial sepsis was defined as any horse developing two or more of } \\
\text { four signs, including lameness, joint distension, synovial white blood } \\
\text { cell count }>10 \times 10^{9} / \mathrm{L} \text {, or synovial total protein }>25 \mathrm{~g} / \mathrm{L} \text { within } 8 \\
\text { weeks of intra-synovial medication of the same joint. Cases that } \\
\text { resolved with conservative therapy (short courses of non-steroidal } \\
\text { anti-inflammatory drugs and antimicrobials) were not diagnosed as } \\
\text { septic. }\end{array}$ \\
\hline $\begin{array}{l}\text { Main findings: } \\
\text { (relevant to PICO question): }\end{array}$ & $\begin{array}{l}\text { - Frequency of iatrogenic synovial sepsis was very low }(0.04 \% \text {, } \\
\text { 4/9456). } \\
\text { 89.3\% of injections (3869/4331) included corticosteroids; } 93.4 \% \\
\text { included amikacin (4044/4331). Dosages were not recorded. } \\
\text { - Four horses developed iatrogenic synovial sepsis - two following } \\
\text { injection of PSGAGs, one following triamcinolone acetonide } \\
\text { combined with amikacin sulphate and one following } \\
\text { triamcinolone acetonide alone. } \\
\text { - Administration of intra-synovial PSGAGs was associated with an } \\
\text { increased risk of iatrogenic synovial sepsis, though the } 95 \% \\
\text { confidence intervals cross 0, therefore this finding was not } \\
\text { statistically significant. } \\
\text { Concurrent injection of amikacin sulphate with any other intra- } \\
\text { synovial medication was associated with a low risk of developing } \\
\text { iatrogenic synovial sepsis (attributable risk -1.02\%, [CI -2.21- } \\
\text { 0.16]), though the confidence interval crosses 0, therefore this } \\
\text { finding was not statistically significant. }\end{array}$ \\
\hline Limitations: & $\begin{array}{l}\text {-93.4\% of injections (4044/4331) included a prophylactic } \\
\text { antibiotic (amikacin sulphate) so true risk of sepsis without } \\
\text { concurrent antimicrobial administration is difficult to quantify. } \\
\text { - Dosages of medications were not recorded. } \\
\text { - High proportion of racehorses within study population may limit } \\
\text { external validity. } \\
\text { - Case definition of synovial sepsis in relation to descriptive clinical }\end{array}$ \\
\hline
\end{tabular}




\begin{tabular}{|l|l|}
\hline $\begin{array}{l}\text { parameters (lameness, joint swelling) was open to interpretation } \\
\text { and may vary between veterinary surgeons. } \\
\text { Data analysed in sessions rather than per individual injection; } \\
\text { there were } 9456 \text { injections performed in total, though data is } \\
\text { analysed over } 4331 \text { sessions. }\end{array}$ \\
$\begin{array}{l}\text { Statistical validity of results is limited by a large number of } \\
\text { injections with relatively low number of septic cases for } \\
\text { comparison (resulting in a low number of events per variable for } \\
\text { analysis of risk factors). }\end{array}$ \\
\hline
\end{tabular}

\section{Appraisal, application and reflection}

The current literature suggests that the frequency of infection following all intra-articular injections (including corticosteroids, antimicrobials, anaesthetic agents, PSGAGs, combinations of the above and any other unspecified or unlisted medication included in the studies reviewed) is very low and equates to roughly one case per 1000 or 2364 injections, according to Steel et al. (2013) and Smith et al. (2018) respectively. These figures equate to a prevalence of iatrogenic sepsis of $0.02-0.08 \%$. The overall prevalence of synovial sepsis following all intra-articular injections based on data from all included studies was calculated as $0.02 \%$ [ $\mathrm{Cl} 0.02-0.03 \%]$. The prevalence of synovial sepsis following corticosteroid injections across three studies which provided the necessary data (Smith et al., 2018 and Steel et al., 2013) was 0.07\% [Cl 0.04-0.012\%].

Table 1: Prevalence estimates for synovial sepsis for all intra-articular injections across all studies (as calculated by author of this Knowledge Summary).

\begin{tabular}{|c|c|c|c|c|}
\hline Study & Injections & Septic cases & Prevalence (\%) & $\mathrm{Cl}(\%)$ \\
\hline $\begin{array}{l}\text { Steel et al. } \\
\text { (2013) }\end{array}$ & 16,624 & 13 & 0.08 & $0.05-0.13$ \\
\hline $\begin{array}{l}\text { Gillespie et } \\
\text { al. (2016) }\end{array}$ & 319,760 & 67 & 0.02 & $0.02--0.03$ \\
\hline $\begin{array}{l}\text { Smith et al. } \\
(2018)\end{array}$ & 9456 & 4 & 0.04 & $0.02--0.11$ \\
\hline ALL & 345,840 & 84 & 0.02 & $0.02-0.03$ \\
\hline
\end{tabular}

Table 2: Prevalence estimates for iatrogenic synovial sepsis following corticosteroid injections in the only two included studies which provided the necessary data (as calculated by the author of this Knowledge Summary).

\begin{tabular}{|l|r|r|r|l|}
\hline Study & \multicolumn{1}{l|l|}{$\begin{array}{l}\text { Corticosteroid } \\
\text { Injections }\end{array}$} & Septic cases & Prevalence (\%) & Cl (\%) \\
\hline $\begin{array}{l}\text { Steel et al. } \\
\text { (2013) }\end{array}$ & 15,934 & 12 & 0.08 & $0.04-0.13$ \\
\hline $\begin{array}{l}\text { Smith et al. } \\
(2018)\end{array}$ & 3,871 & 2 & 0.05 & $0.01-0.19$ \\
\hline ALL & 19,805 & 14 & 0.07 & $0.04-0.12$ \\
\hline
\end{tabular}

From the studies examined, there is no evidence that injecting antibiotics in conjunction with corticosteroids reduces the frequency of synovial sepsis following intra-articular injection. 
There is some evidence indicating that the risk of iatrogenic synovial sepsis following intra-articular medication may be increased by a number of factors, including:

- The veterinary surgeon not performing the skin preparation herself/himself

- The veterinary surgeon being qualified for over 20 years

- Clipping the injection site

- Skin preparation with chlorhexidine for fewer than 7 minutes*

- Not wearing gloves*

- Using the same needle to draw up medications and to inject the joint*

(* denotes factors that were statistically significant on univariable analysis though not on multivariable analysis (Gillespie et al., 2016))

One of the included studies provided weak evidence of an increased risk of synovial sepsis following the injection of PSGAGs. Smith et al. (2018) reported that injection of PSGAGs was positively associated with iatrogenic synovial sepsis, though this finding was not statistically significant. In an abstract found in the literature search (though not included in the Knowledge Summary as it was an unpublished proceedings expanded abstract), Bohlin et al. (2014) also reported that injection of PSGAGs in combination with corticosteroids appeared to increase the risk of infection. Although not included in the summarised evidence due to it not meeting the inclusion criteria, a paper by Gustafson et al. (1989) reported that PSGAGs potentiate the risk of iatrogenic infection. Gustafson found that intra-articular injection of $125 \mathrm{mg}$ amikacin immediately after inoculating the joint with Staphylococcus aureus significantly decreased the potentiation of infection by the PSGAG. From this data, it can be concluded that concurrent injection with antimicrobials when injecting PSGAGs may be warranted. Further studies with larger sample sizes would be required to confirm whether concurrent antibiotic administration when injecting PSGAGs is necessary.

Responsible use of antimicrobials is of paramount importance across all health sectors, and making appropriate, evidence-based choices is crucial to preventing the development of antimicrobial resistance. Therefore, the following recommendations can be made:

- Sterile skin preparation should be performed for a minimum of 7 minutes when using chlorhexidine, ideally by the veterinary surgeon performing the intra-articular injection.

- Gloves should be worn for skin preparation as well as for intra-articular injection.

- Needles should be changed after drawing up medications and before intra-articular injection.

- Veterinary surgeons should consider not clipping the injection site, though this will depend on the length of hair, visibility of landmarks and gross contamination of the surrounding hair and skin.

- Intra-articular injection of antimicrobials is unlikely to be necessary, though may be warranted if PSGAGs are being injected.

Although some of the above factors were only statistically significant on univariable analysis rather than on multivariable analysis, they have been included in the clinical recommendations for performing intra-articular injections as they are factors that may be implemented with ease in a clinical setting. A systematic review of aseptic skin preparation procedures for intra-articular injections in horses would be of benefit to equine practitioners, with particular attention on clipping and the substance used for disinfection (e.g. chlorhexidine or iodine). An investigation of skin preparation protocols in relation to septic arthritis rates would also be of great benefit to equine practitioners.

The quality of the evidence included in this summary is mixed. Only three studies were found and one of those three did not provide enough information regarding exact medications injected (corticosteroids vs others) to accurately interpret the results with direct relevance to the PICO question (Gillespie et al., 2016). None of the studies rank highly in the hierarchy of research and evidence-based medicine (Arlt \& Heuwieser, 2016 and Murad et al., 2016). The poor quality and heterogeneity of the studies precluded meta-analysis of their results. 
In answer to the PICO question, it can be concluded that injecting antibiotics in conjunction with corticosteroids is likely to be unnecessary. However, there is a paucity of strong, evidence based research on the subject. Although the available studies provide useful data, they have limited external validity and insufficient statistical power. Further studies are required in this area to reach a definitive conclusion for this particular PICO question. Given the very low frequency of iatrogenic synovial sepsis following intra-articular injection reported in the included studies, a randomised controlled trial is unlikely to be feasible and a multicenter case control study would likely be required in order to recruit an adequate number of cases to achieve sufficient statistical power.

\section{Methodology Section}

\begin{tabular}{|c|c|}
\hline \multicolumn{2}{|l|}{ Search Strategy } \\
\hline $\begin{array}{r}\text { Databases searched and dates } \\
\text { covered: }\end{array}$ & $\begin{array}{l}\text { CAB Abstracts - } 1973 \text { to } 26 \text { February } 2019 . \\
\text { Pubmed via the NCBI website; } 1910 \text { to } 26 \text { February } 2019 \\
\text { Science Direct - Elsevier - unknown to } 26 \text { February } 2019 \\
\text { Scopus - unknown to } 26 \text { February } 2019 \\
\text { Wiley Online Library - unknown to } 26 \text { February } 2019\end{array}$ \\
\hline Search terms: & $\begin{array}{l}\text { The search terms used for CAB Abstracts, Pubmed, Wiley Online } \\
\text { Library and Scopus were: } \\
\text { Search 1: “(intra-articular OR intraarticular OR intra-synovial OR joint } \\
\text { OR synovial OR articular) AND (injection OR medication OR } \\
\text { administration ) AND (corticosteroid OR cortico-steroid OR steroid } \\
\text { OR corticoid OR betamethasone OR triamcinolone OR } \\
\text { methylprednisolone OR dexamethasone) AND (risk OR risks OR } \\
\text { infection OR sepsis OR complication OR complications) AND } \\
\text { (antibiotic OR antimicrobial OR antibacterial OR amikacin OR } \\
\text { gentamicin OR antibiosis OR anti-microbial OR antibiotics OR } \\
\text { antimicrobials) AND (horse OR horses OR equine)". } \\
\text { Search 2: "(intra-articular OR intraarticular OR joint OR synovial OR } \\
\text { articular) AND (injection OR medication) AND (corticosteroid OR } \\
\text { cortico-steroid OR steroid OR corticoid OR betamethasone OR } \\
\text { triamcinolone OR methylprednisolone OR dexamethasone) AND (risk } \\
\text { OR risks OR infection OR sepsis OR complication OR complications) } \\
\text { AND (horse OR horses OR equine)". } \\
\text { Search 3: “(intra-articular OR intraarticular OR joint OR synovial OR } \\
\text { articular) AND (injection OR medication) AND (antibiotic OR } \\
\text { antimicrobial OR antibacterial OR amikacin OR gentamicin OR } \\
\text { antibiotics OR anti-microbial) AND (horse OR horses OR equine)". } \\
\text { The search terms for Science Direct (which does not support } \\
\text { searches of more than eight Boolean connectors per field), as well as } \\
\text { all of the databases mentioned above were: } \\
\text { Search 4: "(intra-articular OR intraarticular OR joint OR synovial OR } \\
\text { articular) AND (injection OR medication) AND (infection OR sepsis) } \\
\text { AND (horse OR horses OR equine)". }\end{array}$ \\
\hline
\end{tabular}




\begin{tabular}{|l|l|}
\hline & $\begin{array}{l}\text { Reference lists and bibliographies of discovered articles were also } \\
\text { examined to identify other relevant publications, none of which } \\
\text { were found. }\end{array}$ \\
& $\begin{array}{l}\text { The Wiley Online Library search yielded 1344 results with Search 1, } \\
\text { necessitating subject refinement to Veterinary Medicine, Medical } \\
\text { Science and Equine Science. }\end{array}$ \\
\hline Dates searches performed: & 26 February 2019 \\
\hline
\end{tabular}

\section{Exclusion / Inclusion Criteria}

\begin{tabular}{|l|l|}
\hline Exclusion: & $\begin{array}{l}\text { Studies not related to the PICO question } \\
\text { Studies performed in other species } \\
\text { Non-English language publications } \\
\text { Abstract and full text unavailable }\end{array}$ \\
\hline Inclusion: & Studies relevant to the PICO question in the English language \\
\hline
\end{tabular}

Please add rows as necessary 
The author declares no conflicts of interest.

\section{REFERENCES}

1. Arlt, S.P., \& Heuwieser, W. (2016). 'The Staircase of Evidence-a New Metaphor Displaying the Core Principles of Evidence-based Veterinary Medicine'. Veterinary Evidence, 1(1). DOI: $10.18849 /$ VE.V1I1.18

2. Ausvet Pty Ltd. (2019). 'Epitools epidemiological calculators'.

3. Bohlin, A.M., Kristoffersen, M., \& Toft, N. (2014). 'Infectious arthritis following intra-articular injection in horses not receiving prophylactic antibiotics: a retrospective cohort study of 2833 medical records'. In Proceedings of the 60th Annual Convention of the American Association of Equine Practitioners, Salt Lake City, Utah, USA, December 6-10 2014 (pp. 255-256). American Association of Equine Practitioners (AAEP).

4. Gillespie, C.C., Adams, S.B., \& Moore, G.E. (2016). 'Methods and Variables Associated with the Risk of Septic Arthritis Following Intraâ€?Articular Injections in Horses: A Survey of Veterinarians'. Veterinary Surgery, 45(8), pp. 1071-1076. DOI: https://doi.org/10.1111/vsu.12563

5. Gustafson, S.B., Mcllwraith, C.W., Jones, R.L., \& Dixon-White, H.E. (1989). 'Further investigations into the potentiation of infection by intra-articular injection of polysulfated glycosaminoglycan and the effect of filtration and intra-articular injection of amikacin'. American journal of veterinary research, 50(12), pp. 2018-2022.

6. Murad, M.H., Asi, N., Alsawas, M., \& Alahdab, F. (2016). 'New evidence pyramid'. BMJ Evidence-Based Medicine, 21(4), pp. 125-127. DOI: http://dx.doi.org/10.1136/ebmed-2016-110401

7. Peduzzi, P., Concato, J., Kemper, E., Holford, T.R., \& Feinstein, A.R. (1996). 'A simulation study of the number of events per variable in logistic regression analysis'. Journal of clinical epidemiology, 49(12), pp. 1373-1379. DOI: https://doi.org/10.1016/S0895-4356(96)00236-3

8. Smith, L., Palmer, L., Shepherd, M., Steven, W.N., Dallas, R., Baldwin, G., Sommerville, G., Hawthorne, T. and Ramzan, P. (2013). 'Risks of Synovial Sepsis Following Intra-synovial Medication in Ambulatory Practice, 2006-2011: 9456 Intra-synovial Injections'. In: Clinical Research Abstracts of the British Equine Veterinary Association Congress 2013, Equine Veterinary Journal, 45, pp. 6-6. DOI: https://doi.org/10.1111/evj.12145 13

9. Smith, L.C.R., Wylie, C.E., Palmer, L., \& Ramzan, P.H.L. (2018). 'Synovial sepsis is rare following intrasynovial medication in equine ambulatory practice'. Equine veterinary journal. DOI: https://doi.org/10.1111/evi.13063

10. Steel, C.M., Pannirselvam, R.R., \& Anderson, G A. (2013). 'Risk of septic arthritis after intraâ€?larticular medication: a study of 16,624 injections in Thoroughbred racehorses'. Australian veterinary journal, 91(7), pp. 268-273. DOI: https://doi.org/10.1111/avj.12073

\section{Acknowledgement}

RCVS Knowledge was supported in producing this Knowledge Summary by an educational grant from Petplan Charitable Trust. 


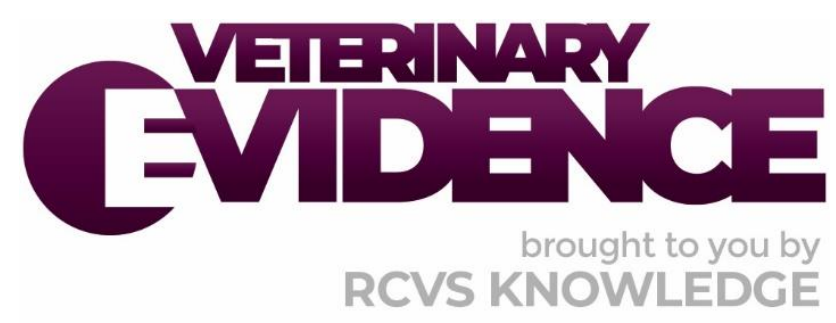

\section{Intellectual Property Rights}

Authors of Knowledge Summaries submitted to RCVS Knowledge for publication will retain copyright in their work, and will be required to grant RCVS Knowledge a non-exclusive license of the rights of copyright in the materials including but not limited to the right to publish, re-

publish, transmit, sell, distribute and otherwise use the materials in all languages and all media throughout the world, and to license or permit others to do so.

\section{Disclaimer}

Knowledge Summaries are a peer-reviewed article type which aims to answer a clinical question based on the best available current evidence. It does not override the responsibility

of the practitioner. Informed decisions should be made by considering such factors as individual clinical expertise and judgement along with patient's circumstances and owners' values. Knowledge Summaries are a resource to help inform and any opinions expressed within the Knowledge Summaries are the author's own and do not necessarily reflect the view of the RCVS Knowledge. Authors are responsible for the accuracy of the content. While the

Editor and Publisher believe that all content herein are in accord with current recommendations and practice at the time of publication, they accept no legal responsibility

for any errors or omissions, and make no warranty, express or implied, with respect to material contained within.

For further information please refer to our Terms of Use.

RCVS Knowledge is the independent charity associated with the Royal College of Veterinary Surgeons (RCVS). Our ambition is to become a global intermediary for evidence based veterinary knowledge by providing access to information that is of immediate value to practicing veterinary professionals and directly contributes to evidence based clinical decision-making.

https://www.veterinaryevidence.org/

RCVS Knowledge is a registered Charity No. 230886.

Registered as a Company limited by guarantee in England and Wales No. 598443.

Registered Office: Belgravia House, 62-64 Horseferry Road, London SW1P 2AF

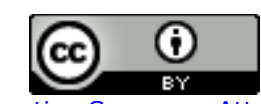

This work is licensed under a Creative Commons Attribution 4.0 International License. 